\title{
“I Make 40 Cents An Hour. What Do You Make?” Labour Militancy at CNIB Sheltered Workshops, 1966-1984
}

\section{Dustin Galer, York University}

From the 1960 s to 1980 s, clients of the Canadian National Institute for the Blind (CNIB) struggled for a new deal while they toiled away in workshops often set up in the basement of CNIB residences across the country. Hundreds of CNIB clients ${ }^{1}$ spent several years of their working lives in sheltered workshops run by the CNIB's job training program manufacturing a broad range of consumer goods. During this period, many workshops had fallen into disrepair and were reportedly not living up to their intended purpose of providing access to the mainstream labour market. As a result, many blind sheltered workers became increasingly disgruntled. Groups of workers in Toronto and Edmonton went on strike, enlisting their allies in the labour movement and emerging disability rights movement to picket the CNIB to help press for changes to the workshop system. Increased labour militancy raised important questions about the state of sheltered workshops in Canada and the role the CNIB played in addressing chronically high unemployment rates in the blind community. Why were sheltered workshops considered an appropriate solution to the poverty and isolation of blind Canadians from the labour market? Who were these blind strikers and their activist allies? Why did they target the CNIB-a celebrated national charitable organization? Was there any legitimacy to workers' claims of neglect, exploitation and inefficiency? This article will explore these and other questions surrounding the evolution of CNIB sheltered workshops during a dynamic period in the history of the disabled working-class in Canada.

\section{Blind Unemployment and the CNIB}

The harsh economic realities of living with a disability in Canada during the twentieth century included high unemployment, chronic poverty, and limited access to affordable housing and income supports. Intersecting barriers to workforce participation kept many people with disabilities out of work. Access to the labour market was particularly blocked for blind people due to prejudicial social attitudes, educational deficits, and physical barriers. Unemployment rates varied across the disability community due to differences in the experience of disability, as well as the statistical measurement and definition of disability, including whether individuals in training programs were counted as unemployed. Unemployment rates of disabled people in Canada throughout most of the latter half of the twentieth century ranged from thirty to ninety per cent. ${ }^{2}$ Most available data regarding employment rates of registered blind Canadians suggest approximately fifty to eighty-five per cent were unemployed during this period. ${ }^{3}$ Unable to secure paid jobs in the mainstream labour 
market, many blind and other disabled people lived in poverty, were dependent on social assistance, and often were unable to secure accessible, quality, affordable housing.

One of the earliest and most prevalent responses to high levels of poverty and unemployment in the disability community included enlisting people to work in sheltered workshops. Sheltered work was conventionally unskilled and non-marketable, and therefore people in workshops gained little actual competitive work experience. Classified as trainees and compensated with symbolic stipends instead of actual wages, sheltered workers were training to become employable rather than gaining skills that in fact made them employable. As a result, workshops were insulated from the economic dynamics in the broader labour market, which also permitted administrators to eschew adherence to traditional labour rights and employment contracts. The symbolic nature of sheltered work also raised larger concerns about the ability of workshops to effectively address the displacement of disabled people from the labour market. ${ }^{4}$

By 1915, workshops for blind people existed in virtually every major Canadian city, churning out consumer products such as brooms, mattresses, and other packaged products for specialty stores and major retailers. ${ }^{5}$ Many workshops were established by local charitable, religious, and non-profit groups concerned about high rates of poverty and unemployment in the blind community. One of the first workshops was founded in 1911 by the Montreal Association for the Blind, and produced various consumer goods for sale locally. ${ }^{6}$ The establishment of the CNIB in 1918 transformed the sheltered employment system. The CNIB quickly took over operation of most existing workshops for the blind in Canada and opened new shops throughout the 1920s and 1930s. Workshops, however, were heavily subsidized by the CNIB. One garment factory that employed blind women flourished in Winnipeg until the mid-1970s. Most of these shops struggled to make a profit, as blind workers manufactured the brooms and then were expected to go door to door to sell them. Often, failure to meet sales targets meant that the suppliers of raw materials could not be paid. That scenario forced one shop to close, and in other cases, the CNIB's national office "juggled funds from one part of the country to another to balance out the viability of these operations." ${ }^{\prime 7}$ Managing the finances of CNIB workshops was a daunting challenge for a young organization that needed ever-increasing sources of funds to meet a growing appetite for training, capital acquisitions, and employment programs. ${ }^{8}$

By 1928, the CNIB further expanded its involvement in the employment of blind people with the introduction of a placement program where CNIB employment officers cultivated networks of employers willing to hire blind workers. The program worked by matching registered clients with paid employment in outside industry. In the same year, the first CNIB lunch counter was launched in Toronto, an operation that quickly ballooned into a nationwide business named CaterPlan. By mid-century, CNIB's CaterPlan and sheltered workshop program pro- 


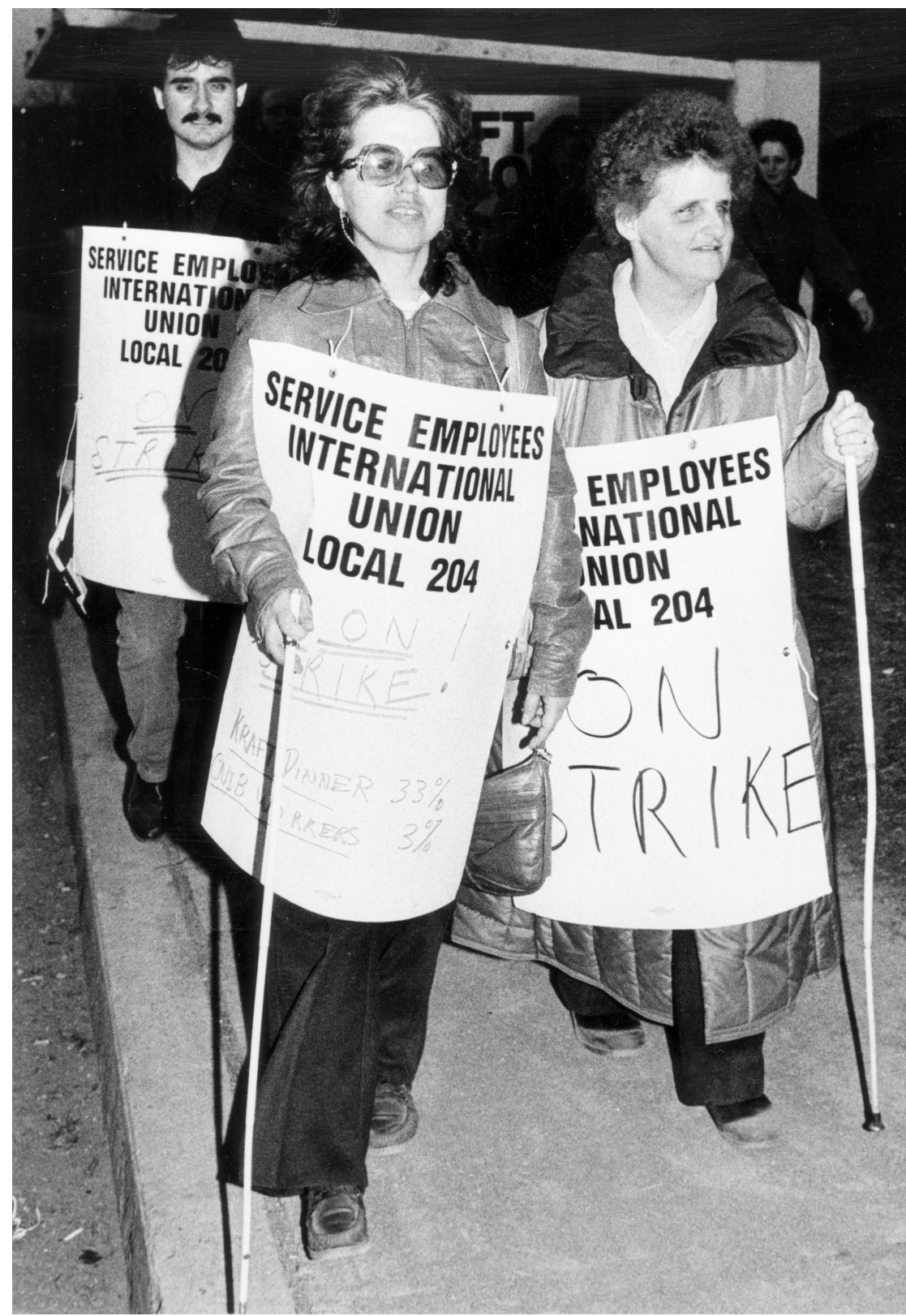

Blind and sighted employees of the CNIB picket the Toronto headquarters, Feb. 23, 1984.

Photo by Thomas Szlukovenyi / The Globe and Mail 
vided employment to thousands of $\mathrm{CNIB}$ clients as employment officers located jobs for blind workers in outside industry. The CNIB held a virtual monopoly on services for the blind and by the post-war era, there was a clear expectation among blind Canadians that the CNIB would either employ them directly, or facilitate access to jobs in the mainstream labour market.

By the 1960s, however, blind workers' relationship with the CNIB became increasingly strained as clients in sheltered workshops failed to make the transition to work in outside industry. Unlike employment services for other people with disabilities, the CNIB held a virtual monopoly on services for blind people, including many job development opportunities and other employment supports used to facilitate access to job opportunities. As the sole provider of employment services to blind people, the CNIB was seen as paternalistic by many in the blind community. Blind jobseekers were typically redirected to the CNIB to access training and certification programs in a limited range of occupations that included typists, telephone operators, and binders. ${ }^{10}$ For some blind sheltered workers, CNIB-run workshops provided the only means to access occupational training or work in settings designed to build skills and employability. Being designated as trainees in shops meant that in order to develop transferable skills and access to CNIB employment officers, many blind sheltered workers remained long past the expected temporary period of their employment, despite access to CNIB employment officers.

In the 1970s, an early disability rights movement encouraged disabled people to demand greater access to social and economic opportunities by resisting passive deference to service organizations, such as the CNIB ${ }^{11}$ Many blind sheltered workers took part in this developing movement, both as workers and consumers of CNIB employment services. Activists demanded the CNIB grant disabled people greater control over disability services, advocating consumer representation on agency boards and committees. Activist mantras were devised by disability activists in Canada or borrowed from abroad and included "Nothing about us without us." These mantras inspired disabled workers to take a stand against the dominant charitable approach to disability issues. ${ }^{12}$ One group, the Blind Organization of Ontario with Self-help Tactics (BOOST), was established on these activist principles. Founded in 1975, BOOST used its proximity to CNIB headquarters in Toronto to advance a provincial and national activist agenda on behalf of the blind community. BOOST joined a wider disability rights movement that demanded better opportunities for disabled people and condemned chronic unemployment and poverty in the disability community.

During the late 1970s and early 1980s, service agencies and government officials grew optimistic that a changing labour market would actually benefit disabled people, and blind people in particular. The CNIB maintained that computers were effective game-changers in the struggle to improve employment opportunities for people with disabilities. Newsletters and journal articles promoted the newest assistive devices and profiled people who applied new computer technologies in 
the workplace. A 1979 column in the Canadian National Institute for the Blind newsletter Employment Services News reportedly provided access to previously inaccessible jobs and generated whole new categories of jobs for blind Canadians. ${ }^{13}$ CNIB writers argued, "More and more companies in Canada are using computers for rapid information retrieval and storage. Now, thanks to modern technology, computer terminals can be used by blind as well as sighted employees."14 Synthesized speech boxes or "talking computers" installed at computer terminals promised to enable blind users to type, edit, print, mail, and monitor incoming and outgoing data efficiently. Such advertisements directly confronted the prejudicial attitudes of employers who maintained that the majority of work was inaccessible to people with visual impairments.

Yet blind sheltered workers and their activist allies argued that disabled people continued to exist on the periphery of the labour market and were exploited by paternalistic service providers that benefited from their cheap labour. ${ }^{15}$ The growth of disability activist politics in Canada in the 1970s helped to expose the poor employment prospects of disabled Canadians, empowering blind sheltered workers to voice their opposition to the status quo and actively resist these conditions. From the late 1960s to early 1980s, blind sheltered workers repeatedly went on strike to demand better wages, working conditions and job security. These strikes connected disabled people with wider social and labour movements demanding greater rights and opportunities for marginalized populations. No longer content to passively accept sheltered work as a legitimate solution to widespread unemployment, blind sheltered workers enlisted a range of supporters and forged new connections with the labour movement to achieve their demands.

\section{Labour Actions at CNIB Workshops}

On a warm spring morning in May 1966, twenty-five broom-makers walked off the job at an industrial facility on Bayview Avenue in Toronto's borough of East York. By Monday, all 175 workers had abandoned their workstations to join the broommakers on the picket lines. Regular commuters and out-of-towners visiting nearby Sunnybrook Hospital on this busy stretch of road might have been surprised to observe blind strikers walking arm-in-arm with sighted colleagues or guided by service dogs, waving placards that demanded higher wages and better working conditions. Workers complained they earned twenty-five cents per hour below the one dollar per hour minimum wage, due to exemptions to provincial minimum wage legislation. ${ }^{16}$

Predominantly blind workers recently unionized by the Service Employees International Union (SEIU) worked out of six sheltered workshops at the flagship headquarters of the CNIB. Certainly, this was no ordinary strike and these were no ordinary workers. For many, the CNIB was employer, landlord, service provider, and even banker - a virtual mill-town in the middle of one of Canada's most populous cities. Unskilled and semi-skilled sheltered workers produced a range of con- 


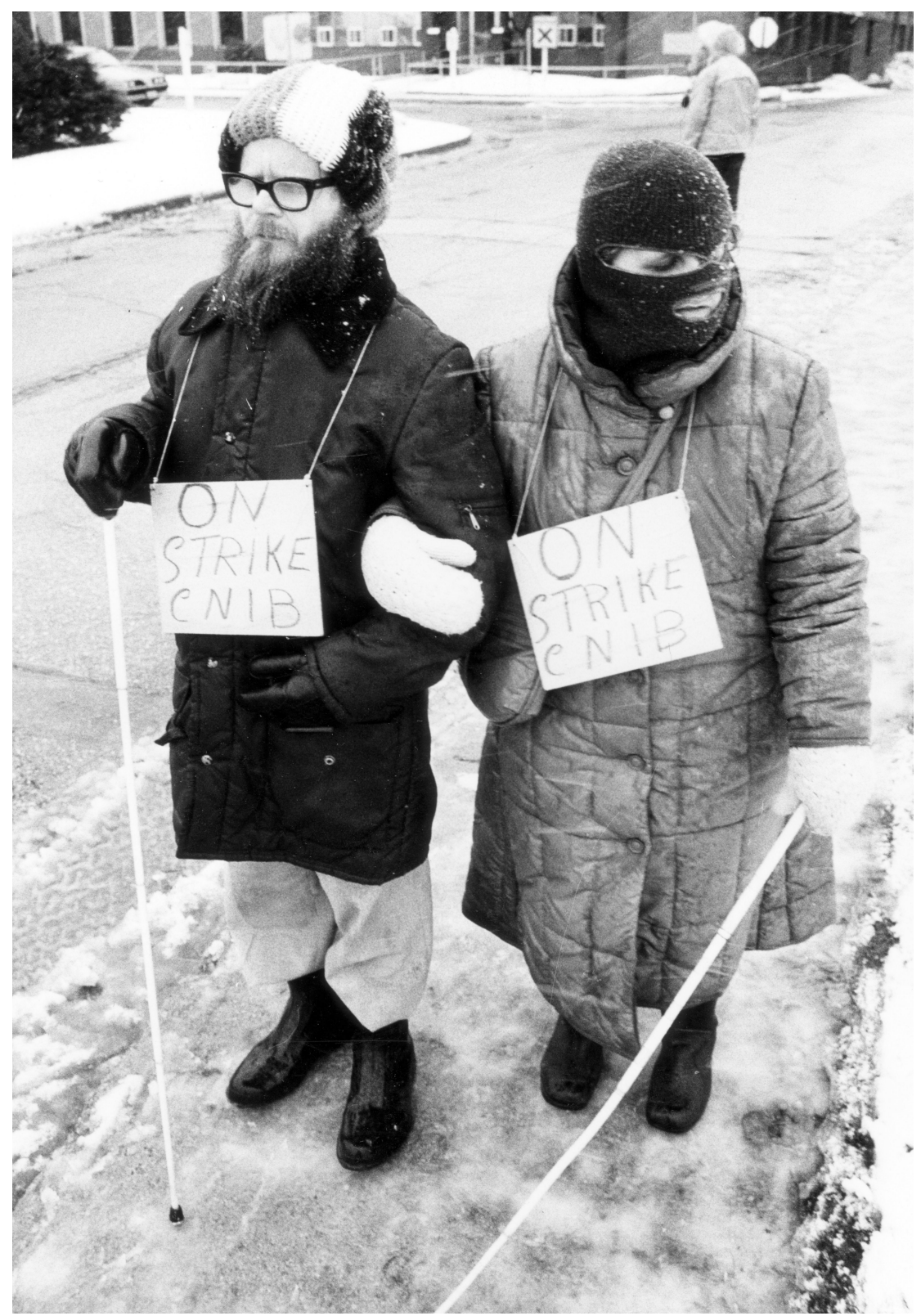

Two blind CNIB employees, David Gunness and Donna Renaud, hold down the Toronto line in February 1984 after nearly forty days.

Photo by Donald Grant / The Globe and Mail 
sumer goods for sale in CNIB retail outlets and mainstream stores, but technically worked as clients of CNIB's employment programs. Many workers lived on-site or in nearby housing, also run by the CNIB, and their work was considered part of an occupational training program. The strike occurred before the advent of the disability rights movement and with no allies. Consequently, the strikers saw little hope in continuing their struggle and after seven days on the picket lines, settled for marginal wage increases in exchange for an immediate return to the production lines.

In 1977, blind employees of CNIB's CaterPlan Services argued they lacked job security. Unlike trainee-workers in industrial workshops, CaterPlan workers were considered employees of the CNIB. Many blind CaterPlan workers came from sheltered workshops, having been placed there by CNIB employment officers. Organized by the Canadian Union of Blind and Sighted Merchants (CUBSM), CaterPlan merchants often worked in virtual isolation from one another in concession stands and lunch counters across the country. As collective bargaining talks between CUBSM and CNIB broke down in mid-February following the expiration of their contract in October 1976, workers in the Greater Toronto Area organized pickets at CNIB headquarters. Although they had negotiated a new, two-year contract with progressive wage increases, blind merchants argued they were unable to count on CaterPlan as a stable employer. By 24 March, 40 of CUBSM's 110 blind merchants out of approximately 500 total employees in 163 units across the country took turns holding down the picket line along Bayview Avenue in order to exert continuous pressure on CNIB management. One picketer, Charles Hughes, noted he “didn't see anything unusual about the blind picketing the blind," referencing a culture of protest among blind workers confident in exercising their labour rights against the substantial resources of the CNIB. ${ }^{17}$

Sheltered workers struck again in 1979 at CNIB's Edmonton facility. Echoing complaints voiced thirteen years earlier by their Toronto colleagues, the Edmonton strike highlighted a deteriorating, substandard workplace and extremely poor wages. The workshop was located in the basement of the Edmonton CNIB residence where many workers also lived. In fact, the workshop was designated "dangerously overcrowded" by a provincial health and safety inspector, reportedly featuring "gaping holes," a significant volume of sawdust in the air, and narrow aisles between stacks of sharply pointed surveyor stakes. ${ }^{18}$ Picketing workers waved placards that read "I make 40 cents an hour. What do you make?" at a time when the provincial minimum wage was three dollars per hour. ${ }^{19}$ Workers also complained the CNIB was "exploiting the blind and making a considerable profit from the workshop." ${ }^{20}$ Strikers argued that the workshop, part of CNIB's employment training program, did not lead to jobs in outside industry according to one individual who said he had been at the workshop for more than six years without placement. Unlike Toronto strikers in 1966, the Edmonton strike benefited from a growing national disability rights movement that progressively built links with the Canadian labour movement. Eleven days after the strike began, representatives of the Cana- 
dian Union of Public Employees (CUPE) joined the picket lines to demonstrate their support of sheltered workers. CUPE's endorsement also came with promises of compensation to the strikers, providing crucial financial and moral support to the strike effort, which lasted thirty-three days before a settlement was reached with the assistance of an Alberta Federation of Labour mediator.

In 1981, another type of protest took place at CNIB headquarters. With the rise of the disability rights movement and growing public awareness of disability labour issues, groups of blind activists advanced a rights agenda for CNIB clients. Based in Toronto, blind activists associated with BOOST led a movement against CNIB to allow greater consumer control over daily operations. One of the top priorities identified by BOOST was to dismantle the sheltered workshop system, which, they argued, denied blind people their agency and contributed to poverty and dependency on the CNIB. In 1980, BOOST released a report titled "Developing Alternative Service Models" (DASM), calling for an overhaul of services for the blind including an end to minimum wage exemptions and new measures to ensure sheltered workers found jobs in outside industry. ${ }^{21}$ In line with their consumer activist agenda, BOOST organized a demonstration in May 1981 outside CNIB headquarters during a national board meeting. BOOST organized the event following months of unsuccessful attempts to communicate effectively with the CNIB President and Managing Director. ${ }^{22}$ BOOST activists were responding to the perceived lack of transparency and unwillingness on the part of CNIB management to engage in meaningful dialogue or share decision-making with blind consumers. CNIB staff refused BOOST members entry to the meeting, rejecting the assertion that the current model of service delivery had been unsuccessful. In a public statement to the press, BOOST voiced the concerns of sheltered workers, asking:

Why are 75 per cent of working-age blind people unemployed? Why are so many of the working blind employed in CNIB sheltered workshops? Why are more jobs not available when CNIB Boards are heavily populated with businessmen? Why are so many blind people living below the poverty line? ${ }^{23}$

In February and March 1984, blind sheltered workers in Toronto embarked upon their longest struggle yet with the CNIB. A massive strike virtually halted manufacturing and service operations at CNIB headquarters. SEIU Local 204, representing seventy sheltered and regular workers, walked off the job demanding twice what the CNIB offered, namely three per cent wage increases over two years. The CNIB's Executive Director argued the organization was financially constrained by "inflation, lower income on investments and restraint programs of the federal and Ontario governments." ${ }^{24}$ A spokesperson from SEIU stated sheltered workers made minimal wages and suffered from years of "mediocre settlements" that left members unable to keep up with the pace of inflation. ${ }^{25}$ Unionized blind workers, motivated by the momentum of a growing disability rights movement, demanded greater equity with their sighted colleagues whom they argued 
were consistently "shown preference in terms of promotions." 26 Blind and sighted workers were paired together and walked the picket lines in solidarity, carrying placards that stated they were "seeing red" and that the CNIB was "robbing us blind."27 After nearly forty days, with strike funds depleted and social assistance cheques completely stretched, workers voted to accept a settlement for marginal wage increases and no guarantees of job parity between blind and sighted workers.

\section{Analysis of Labour Militancy in CNIB Workshops}

From the 1960s, blind Canadians voiced their frustration with the poor state of services for the blind, which, they argued, failed to promote their social and economic integration. Former managing director of the CNIB, Euclid Herie, condemned labour action by blind sheltered workers, arguing it embarrassed the blind community generally and the CNIB specifically. He stated:

Blind people picketing on sidewalks outside CNIB buildings, some with guide dogs or white canes for maximum visual effect, might have invited comparison to those blind beggars from days long gone. But vocal, strident blind people waving placards at staff and passersby did nothing to support the CNIB's image as a professional, prestigious service organization with the best interests of its clients in mind. ${ }^{28}$

Vision Canada, a 1976 landmark study by Cyril Greenland, investigated the state of services for blind Canadians, and concluded that many "unmet needs" caused growing resentment and anxiety that led some people with visual impairments to question the effectiveness of CNIB services. ${ }^{29}$ Despite the CNIB's eighteen specialized employment counsellors, for example, only thirty per cent of registered blind people in Ontario were gainfully employed in 1974, primarily within CNIB's CaterPlan business venture or in CNIB-run sheltered workshops. ${ }^{30}$ Greenland also discovered a generation of blind youth among CNIB clientele who were increasingly intolerant of the CNIB and its apparent failure to help them achieve full participation in society. This cohort of blind youth was largely contrasted against an older generation which represented approximately fifty per cent of CNIB clients and who were emotionally and financially dependent on the CNIB. Greenland recommended the CNIB help bridge this generational and ideological gap by decentralizing its services and improving consumer representation on its administrative boards and in the provision of employment services. ${ }^{31}$ The Greenland report revealed that despite management's assurances that the CNIB was fully capable of integrating people with visual impairments into the mainstream labour market, there remained a significant shortfall in CNIB clients who actually found jobs in this way.

An important cause of increased militancy in sheltered workshops included the nature of CNIB's relationship to blind clients. Affordable housing had long been an issue taken up by the CNIB, which provided low-rent apartments to clients in need. Many sheltered workshops were set up in the basements of CNIB 
residences, meaning that many blind sheltered workers lived and worked under the same roof. Access to job training and placement was streamlined through CNIB employment offices, which set the agenda for clients' skill development and provided access to available job opportunities. If clients sought to take out loans for mortgages or other major expenses, such as a business start-up, the CNIB would often provide the necessary financing.

This virtual monopoly ultimately played a paternalistic role in the lives of blind people, particularly for those who relied upon sheltered work for job skill development and income to supplement poverty-level social assistance. The growth of disability activism challenged the CNIB's long-held control over services for the blind. Blind rights activists wanted consumer representation on CNIB boards and meaningful direct participation in the decision-making processes. CNIB managers, however, were generally unwilling to share power with consumers and restricted their engagement with disability rights organizations. As John Lord stated in his book Impact, which recounts the history of the independent living movement, service organizations during this early period of the disability rights movement often responded with the attitude "we already do that," effectively shutting down the discussion. ${ }^{32}$

Indeed, this was clearly the approach taken by CNIB management in response to BOOST's requests to participate in CNIB governance. In his rather whiggish institutional history of the CNIB, Euclid Herie wrote of BOOST:

This group would pressure and antagonize the CNIB relentlessly. Their attacks came in many forms, reminiscent of the Sol Olinsky [sic] school of protest that included locked-arm protests and a vigorous media campaign urging the CNIB to unlock its boardroom door to have open meetings and let them be board members. In expressing their concerns, BOOST said the CNIB was a closed, secretive, paternalistic organization with a monopoly on services to the blind. BOOST claimed that blind people had no say in policy formation, an assertion which was at best unfair and at worst untrue. The CNIB was unmoved. ${ }^{33}$

Correspondence and media reports between CNIB and BOOST indicate a general unwillingness on the part of CNIB to revise the composition of its board of directors in a manner that was more favourable to consumer activists.

Labour actions at CNIB workshops also helped stimulate greater rights activism within the blind community. As BOOST observed, "the public is familiar with the image of a blind man behind the counter, dispensing candy or coffee in many public buildings, but the public does not know the problems faced by that man behind the counter." 34 The struggles of blind sheltered workers provided an opportunity for blind activists associated with BOOST to publicly denounce sheltered employment while advancing a consumer-led alternative service model. Blind activists were key members of a developing disability rights movement in Canada, 
which focused on transforming disabled peoples' shared experiences of social and economic barriers into ameliorative political action.

In the post-war period, many people with disabilities were excluded from various opportunities to participate in the life of the community by socially-constructed barriers. Successive waves of activism during the twentieth century gradually transformed the physical, political, and discursive landscape in Canada, ultimately moving toward a more accessible and inclusive society. ${ }^{35}$ Inaccessible public spaces and workplaces prevented blind people from full participation in mainstream settings, forcing many people to rely upon the intervention of the CNIB as the conduit to social and economic opportunities. Inspired by civil rights movements at home and abroad, blind activists helped build the disability rights movement in Canada by highlighting the inequity of inaccessibility and promoting alternatives to the status quo. Indeed, the media attention garnered around the 1979 strike at Edmonton CNIB sheltered workshops galvanized blind activists who were intent on forcing change upon the CNIB. BOOST's 1980 DASM manifesto report, with its provisions designed to safeguard the rights of blind sheltered workers, followed directly from the labour struggles at the Toronto and Edmonton workshops.

Strikes at CNIB workshops also occurred at important moments in the evolution of the disability rights activists' relationship with the labour movement. The strikes provided an opportunity for other Canadian unions to demonstrate their support for sheltered workers and laid the groundwork for collaboration between disability and labour activists. CUPE lent its support to blind sheltered workers on the picket lines, helping to both publicize and legitimize the struggles of sheltered workers. Strikers alleged that wages, working conditions, vocational training, and placement services at CNIB and its CaterPlan retail outlets were grossly substandard. ${ }^{36}$ Throughout the controversy, the CNIB maintained that sheltered workers were not employees but rather trainees in job training programs and therefore did not really have the right to strike. The strikers, however, pointed out that while sheltered workers earned approximately forty cents an hour as a result of being classified as trainees, the CNIB reaped considerable profits from the sale of goods and services and savings from labour costs. ${ }^{37}$ Many workshops also engaged in a process known as "creaming," whereby productive workers were held back from "graduation" in order to satisfy the production targets stipulated by funding contracts. ${ }^{38}$ Indeed, many sheltered workers remained in sheltered employment for years without much hope of finding jobs in outside industry. By throwing its support behind frustrated and angry sheltered workers, CUPE signalled the labour movement's support for efforts to reform or abolish the sheltered workshop system in Canada.

CUPE's move to support blind workers dovetailed with the labour movement's growing opposition to sheltered workshops, which labour activists perceived to be inherently exploitative and potentially undermining to wage workers in the competitive labour market. Opposition to sheltered employment by Canadian unions created an opportunity for the labour movement to demonstrate its support 
for a growing disability rights movement. Labour organizations rejected the notion that workshops were a legitimate part of the rehabilitation industry and threatened to undermine labour standards. In response to growing opposition to workshops, another major union, the National Union of Public and General Employees (NUPGE) announced a national campaign in 1981 to lobby all levels of government to review and abolish legislation that permitted exemptions from minimum wage standards, calling such permits hypocritical and exploitative. ${ }^{39}$ NUPGE argued that service agencies' argument that sheltered work was therapy and not a proper employment relationship was a fallacy. NUPGE pointed out that many sheltered workers worked full days in regular work settings, were supervised, punched time clocks, took regular lunch hours, and produced products that were sold for profit. NUPGE President John Fryer stated, "if the work is indeed therapeutic, and prepares them for other employment, then why are so many of them in these workshops for so many years? They are in fact dead-end jobs, with no hope for advancement." ${ }^{40}$

A major plank of the labour movement's campaign in opposition to sheltered employment included an organizing drive. NUPGE and the CLC instituted a plan to organize sheltered workers across the country in order to press for better wages and working conditions. Workshop advocates and service agencies reacted to the campaign with a combination of anger and disbelief. The Canadian Council of Rehabilitation Workshops (CCRW) resented unions' incursion into social service programing and rebuffed the proposal to organize sheltered workshops, citing the fact that workshop clients were classified as trainees in vocational rehabilitation programs. ${ }^{41}$ CCRW President Kenneth Cope told the Globe and Mail that his organization was "very disappointed that the labour movement appears to be limiting itself simply to organizing disabled workers who ask for help, while there are other actions labour could also take which would be of far greater benefit to all disabled people whether they are employed in workshops or not." ${ }^{42}$ Cope argued that unions were ignorant about the dynamics of sheltered work and the rehabilitation industry. Cope pointed out that while the CCRW supported the principle of upholding minimum wage legislation, it was impossible to justify the payment of minimum wages in workshops since the average worker contributes approximately fifty per cent below the productivity relative to the minimum wage. Despite fundamental differences in the outlook of their respective organizations, the CCRW determined it would develop ways to cooperate with the labour movement in the interests of fostering a meaningful dialogue on the labour market integration of disabled people. By 1990 , however, it became apparent this collaborative relationship had failed to materialize as the CCRW repeated the argument that unions "generally frown on arrangements where workshops and supported employment agencies receive non-union subcontracting work from unionized employers." ${ }^{43}$ Instead, the escalation of the opposition to sheltered work, which had its roots in CUPE's support for blind sheltered workers, had the more immediate effect of driving the labour movement into closer association with disability rights activists. 
The struggles of blind sheltered workers and their allies helped encourage the abandonment of the sheltered workshop model in Canada. Following the unsuccessful launch of a federally-sanctioned initiative designed to revitalize workshops by building their revenue-producing capacity, the CNIB workshop strikes highlighted the extent to which segregation and poor labour market outcomes were at the core of sheltered employment, since there was little incentive to pay sheltered workers minimum wages or anything above what they earned. Public opinion of workshops was in serious decline by the early 1980s. Complaints of unfair labour practices, poor working conditions, mismanagement of funds, violation of minimum wage legislation, and funding disincentives that held back productive workers hit news outlets across the country. ${ }^{44}$ Workshops were even associated with "slave" or "sweatshop" labour in certain accounts. ${ }^{45}$

The struggles of blind sheltered workers did nothing to restore the crumbling image of sheltered workshops. Media coverage of blind strikers helped put a human face on the sheltered workshop debate, of which most Canadians likely knew little. While the public image of the $\mathrm{CNIB}$ was relatively unscathed, disability activists used this increased attention on CNIB sheltered workshops to voice the complaints of disabled people and their allies about the exploitative nature of sheltered employment. The idea of blind and disabled people toiling away in substandard workshops for a pittance was universally repugnant. The accepted wisdom was, and continued to be, that workshops were necessary for some people depending on the type and severity of impairment. It became increasingly clear, however, that CNIB workshops for the blind, and perhaps all sheltered employment, strayed from the transitional nature of sheltered employment. Working in a sheltered workshop was never intended to be a permanent alternative to competitive employment, yet this had become the reality for too many unemployable people who "trained" for paid jobs that never materialized.

By the mid-1980s, the CNIB, through its participation in CCRW, increasingly abandoned the sheltered workshop model as the focus shifted to placing more blind people in mainstream jobs in outside industry. Perceiving growing opportunities for blind workers in mainstream workplaces due to new rights legislation and an increasingly computerized workplace, CNIB officials took the opportunity to reconfigure employment services, scaling back the popular (but resource-intensive) job placement officers and closing workshops. And yet, the problem of chronically high unemployment rates in the blind community had not changed much since the 1960s. To critics, sheltered workshops failed to live up to their primary purpose of training blind people for jobs in outside industry. Closing most workshops across the country also made sense to $\mathrm{CNIB}$ officials in the context of corporate restructuring to "modernize" services. Aging structures that housed CNIB clients - and the increasingly notorious workshops — were closed in the 1980s in Edmonton, Vancouver, and Ottawa. As Herie noted, "the residences had grown old along with the people they housed." 46 Although media perception was harsh, many of the res- 
idences were not filled to capacity and since the workshops were attached, they too were phased out. Herie explains:

By 1990, many workshops were gone, leaving only a small program in Calgary and three programs in Ontario (in Sudbury, Hamilton, and Toronto). These closures marked the end of an era in employment that had spanned well over a century. ${ }^{47}$

In Quebec City and Montreal, the CNIB sold the workshops to a consortium of blind workers, but failed to save the broom shop in Toronto- the last workshop to close in 2001.

Sheltered workshops played a central role in the lives of many blind Canadians throughout much of the twentieth century, but critics increasingly questioned their legitimacy as an effective solution to poverty and unemployment. Impelled by rising waves of labour militancy among organized sheltered workers, disability activists and their allies in the labour movement pursued a campaign to transform, and later eliminate, the field of sheltered employment. On the picket lines and in the media, blind sheltered workers and their allies voiced their objection to a life of segregation and poverty. Part of this agenda required presenting service recipients' perspective of $\mathrm{CNIB}$ services, which was clearly different from institutional accounts. While they may not have been successful in their immediate goals, these actions indicated that blind sheltered workers confidently responded to a growing culture of protest within and outside the blind and disability communities. Sheltered workers resented the paternalistic approach of the CNIB and demonstrated their agency by actively taking steps to facilitate change. These actions illuminated the realities of living with disabilities at a key moment in the evolution of disability rights activism in Canada, and set the stage for later developments. 


\section{NOTES}

Regarding the term clients: This term was chosen over others because it distinguishes individuals from the classification of workers or employees. CNIB administrators did not see blind sheltered workers as employees, but as clients of their vocational programs. This is an important distinction and helps explain the administrators' dismissal of sheltered workers who went on strike: how can clients go on strike when they are not seen as employees?

April D'Aubin, "We will ride: a showcase of CCD advocacy strategies in support of accessible transportation," in Making Equality: History of Advocacy and Persons with Disabilities in Canada, ed. Deborah Stienstra, Colleen Watters and Aileen Wight-Felske (Concord, Ont.: Captus Press, 2003), 112; Michael Prince, Absent Citizens: Disability Politics and Policy in Canada (Toronto: University of Toronto Press, 2009), 23.

Mary Bunch and Cameron Crawford, "Persons with Disabilities: Literature Review of the Factors Affecting Employment and Labour Force Transitions," Human Resources Development Canada (1998).

Dustin Galer, "A Place to Work Like Any Other?" Sheltered Workshops and the Evolution of Disability Advocacy in Canada, 1970-1985," Canadian Journal of Disability Studies 3:2 (2014).

Euclid Herie, Journey to independence: Blindness—the Canadian Story (Toronto: Dundurn Press, 2005): 105-7.

Katherine Horne, "An Examination of Evolving Policy and Practice in the Rehabilitation Field in Manitoba, in Relation to Stance and Ends-in-View; and An Exploration of Possible Futures.” (MA thesis, University of Manitoba, 1981), 20.

Herie, 107.

Ibid., 107.

Ibid., 105-107.

Herie, 117.; Graeme McCreath, The Politics of Blindness (Vancouver: Granville Island Publishing, 2011), 27.

Aldred Neufeldt, "Growth and Evolution of Disability Advocacy in Canada," in Making Equality: History of Advocacy and Persons with Disabilities in Canada, ed. Deborah Stienstra, Colleen Watters and Aileen Wight-Felske (Concord, Ont.: Captus Press, 2003), 14-33.

James Charlton, Nothing About Us Without Us (Berkeley, CA: University of California Press, 1998), 46-47. 
AO, RG 7-148, Box B100558, File "Speeches/TV," Article, CNIB, Employment Services NEWS 2:2 (1979).

Ibid.

See Iris Marion Young, "Five faces of oppression," Geographic thought: A praxis perspective (2009): 55-71.

Statistics Canada, "Hourly Minimum Wages in Canada for Adult Workers," (viewed May 10, 2015). Available at http://srv116.services.gc.ca/rpt2.aspx?lang $=$ eng\&dec $=2$

"Blind who run catering booths picket CNIB over job security" The Globe and Mail, 24 March 1977.

Handicapped Communications Society, The Spokesman, (September 1979), 9.

"Hourly Minimum Wages in Canada for Adult Workers"

Handicapped Communications Society, The Spokesman, (September 1979), 9.

John Rae, Anne Musgrave, and Mike Yale, Selfhelp and Government Commitment: A Call to Action: A Report from the Project Developing Alternative Service Models (Toronto: Blind Organization of Ontario with Selfhelp Tactics, 1980).

"Ontario Blind Picket CNIB Demanding Access to Own Files," Our Future: Ontario's Independent Newspaper By and For Handicapped Persons and their Community 6:3 (1979).

LAC, 4304-3-2 (1), BOOST, "Blind people continue their protest over closed system at CNIB,” 14 May 1981.

Thomas Claridge, "70 on strike a month at CNIB want more than $3 \%$ increase," Globe and Mail, M4, 23 March 1984.

Ibid.

Ibid.

"70 on strike a month at CNIB want more than $3 \%$ increase" Herie, 156.

Cyril Greenland, Vision Canada: The Unmet Needs of Blind Canadians (Toronto: Canadian National Institute for the Blind, 1976), 43.

Greenland, Vision Canada, 42.

Ibid., 43.

32 John Lord, Impact: Changing the Way we View Disability: The History, Perspective, and Vision of the Independent Living Movement in Canada (Ottawa: Creative Bound International, 2010). 
${ }^{33}$ Herie, 168. Disability historian Geoffrey Reaume said Herie's study "takes a top-down approach with leading figures in the organization's history predominating in the narrative, leaving a history from service recipients' perspectives waiting for future studies.” Geoffrey Reaume, "Disability History in Canada: Present Work in the Field and Future Prospects," Canadian Journal of Disability Studies 1:1 (2012). For more on the concept and influence of "total institutions" in society see Erving Goffman, "On the characteristics of total institutions," in Symposium on preventive and social psychiatry, (1961): 43-84; Christie Davies, "Goffman's concept of the total institution: Criticisms and revisions," Human Studies 12.1 (1989): 77-95.

${ }^{34}$ John Rae et al, Selfhelp and Government Commitment, 214.

${ }^{35}$ Dustin Galer, “'Hire the Handicapped!' Disability Rights, Economic Integration and Working Lives in Toronto, Ontario, 1962-2005," (PhD dissertation, University of Toronto, 2014).; Aldred Neufeldt, "Growth and Evolution of

Disability Advocacy in Canada," in Making Equality: History of Advocacy and Persons with Disabilities in Canada, ed. Deborah Stienstra, Colleen Watters and Aileen Wight-Felske (Concord, Ont.: Captus Press, 2003), 14-33.

${ }^{36}$ MA, CCD Fonds, Box P5367, File 30, Newsletter, Handicapped Communications Society, The Spokesman, 12:9 (September 1979).

37 Ibid.

38 "Wage Permits for Handicapped Employees."

39 AO, RG 7-148, Box B100660, File “News Clippings,” Article, National Union of Public and General Employees, "NUPGE Program to Assist Disabled Workers," Canadian Labour (October 1981).

40 Ibid.

41 “Group Rejects Union Scheme for Disabled," Globe \& Mail (16 October, 1981).

42 Ibid.

43 CCRW, "Labor's Awareness of Supported Employment," Ability \& Enterprise 4:2 (1990).

44 AO, RG 7-149, Box B363026, File "Speeches/TV," Memo, Handicapped Employment Program, 1 Apr 1982. In April 1982, an internal memo at the Ontario Ministry of Labour pointed to "renewed media interest in sheltered workshops," including a 15-minute segment on CBC's "Metro Morning," with similar features on CTV's program "W5," as well as CFTO. Other news articles included: Roona Maloney, "Hearing People are Outsiders at Centre for the Deaf," Globe and Mail P14 (9 September 1981).; Arthur Moses, "Not Paid Minimum Wage, Cerebral 
Palsy Victim Suing Ontario," Globe and Mail P10 (12 October 1981); "Group Rejects Union Scheme for Disabled," Globe and Mail P10 (16 October 1981).; OMOD, The Advocate (Jul/Apr 1981).; Handicapped Action Committee, HACing Away 2:2 (February 1982).; OMOD, "Awareness Theme of Employment Conference," The Advocate (Nov/Dec 1981).

45 "Clients or Employees: No Minimum Wage for Disabled Workers," Hamilton Spectator (22 October 1983); “"Disability Myth' Hard-Hitting Documentary on Plight of Disabled," Montreal Gazette (10 September 1982); The Disability Myth: Part II: Employment: Beggars Can't Be Choosers, 1982.

${ }^{46}$ Herie, 185.

47 Ibid. 